\title{
Invasion by saffron cod Eleginus gracilis into nearshore habitats of Prince William Sound, Alaska, USA
}

\author{
Scott W. Johnson*, John F. Thedinga, A. Darcie Neff \\ National Oceanic and Atmospheric Administration, National Marine Fisheries Service, Alaska, and Fisheries Science Center, \\ Auke Bay Laboratories, 17109 Pt. Lena Loop Road, Juneau, Alaska 99801, USA
}

\begin{abstract}
We recently identified saffron cod Eleginus gracilis as a dominant fish species in nearshore habitats (<5 m deep, <20 m offshore) of western Prince William Sound (PWS), Alaska, USA. Saffron cod have not been previously reported in PWS, and their capture suggests that fish community structure has changed in nearshore habitats. Nearly 16000 saffron cod were captured in 49 of 95 beach seine hauls at 8 locations in western PWS in 2006 and 2007. Saffron cod accounted for $32 \%$ of the total fish catch (49060 fish, 45 species). Abundance of saffron cod differed by season and habitat type; catch was greater in summer and fall than in spring, and fish were captured almost exclusively in eelgrass Zostera marina habitat. Most saffron cod captured were Age-0; based on age from otoliths, mean size of Age-0 fish increased from $70 \mathrm{~mm}$ total length (TL) (n = 8) in July to $108 \mathrm{~mm}$ TL $(n=21)$ in September. Age-0 saffron cod consumed predominantly pelagic fauna (oikopleurans), whereas fish aged $\geq 1$ targeted predominantly epibenthic fauna (polychaetes and crustaceans). Most saffron cod left the nearshore area by late summer; of 1002 fish that were fin-clipped and released at 1 sampling location (eelgrass) in July 2007, only 2 were recaptured in late August 2007. Reasons for the sudden and dramatic increase in the abundance of saffron cod in western PWS are unclear; possible ecological implications, however, include competition for food and space and increased predation risk to commercially important and forage fish species.
\end{abstract}

KEY WORDS: Eleginus gracilis $\cdot$ Saffron cod $\cdot$ Distribution $\cdot$ Nearshore habitat $\cdot$ Biology $\cdot$ Alaska

\section{INTRODUCTION}

The saffron cod Eleginus gracilis belongs to the Family Gadidae, which includes the Pacific cod Gadus macrocephalus, the Pacific tomcod Microgadus proximus, and the walleye pollock Theragra chalcogramma. In Alaska, saffron cod occupy coastal waters (usually $<60 \mathrm{~m}$ deep) from the Arctic Ocean to as far south as Sitka; however, few saffron cod are caught in the Gulf of Alaska (Mecklenburg et al. 2002). In a long timeseries (1953 to 2007) of small mesh trawl surveys in the western Gulf of Alaska, saffron cod were reported in catches only from 2002 to 2007 (Jackson 2003, 2008); no saffron cod were reported in catches from 1953 to 2001 (Anderson \& Piatt 1999, Ruccio 2003). In the northern Gulf of Alaska (Prince William Sound, PWS), we captured large numbers of saffron cod in nearshore $(<5 \mathrm{~m}$ deep, $<20$ m offshore) habitats in 2006 and 2007; this is the first documented account of saffron cod in PWS. Saffron cod appear to be increasing in distribution and abundance in the northern Gulf of Alaska, and the reasons for this change are unclear.

The nearshore fish community in western PWS is diverse. Dominant species identified in SCUBA surveys include the Pacific cod, the Arctic shanny Stichaeus punctatus, the crescent gunnel Pholis laeta, and several species of greenlings (Hexagrammidae) and sculpins (Cottidae) (Laur \& Haldorson 1996, Dean et al. 2000). Other species identified in beach seine surveys include the juvenile pink salmon Oncorhynchus gorbuscha, the Pacific tomcod, and the walleye pollock (Wertheimer \& Celewycz 1996). Forage fish species such as the capelin Mallotus villosus, the Pacific herring Clupea pallasii, and the Pacific sand lance Ammodytes hexapterus use the nearshore habitat in PWS for spawning and nursery (Robards et al. 1999a, Norcross et al. 2001, Brown 2002, 
Cooney 2007). Saffron cod, however, have not been reported in any PWS studies following the 1989 'Exxon Valdez' oil spill (Laur \& Haldorson 1996, Wertheimer \& Celewycz 1996, Dean et al. 2000).

Published information on the biology of saffron cod in US waters is limited or outdated. Wolotira (1985) provides some information on distribution, size, and age composition of saffron cod from trawl surveys in western Alaska in the late 1970s and a summary of life history data from several Russian studies. Some limited studies have also been done on saffron cod food habits and energy density in the Chukchi Sea (Coyle et al. 1997, Smith et al. 1997) and on habitat associations in nearshore waters of Kodiak Island, Alaska (Laurel et al. 2007).

Saffron cod are not commercially important in Alaska, but are commercially important in many areas of the northwestern Pacific, particularly in Russia (Wolotira 1985, Cohen et al. 1990). Saffron cod are targeted by some subsistence fisheries in Alaska (Mecklenburg et al. 2002), and the potential for a small boat fishery in western Alaska was investigated in the late 1970s (Wolotira 1985). The 2 commercially important gadid species in Alaska, the walleye pollock and the Pacific cod, accounted for 71 and $11 \%$ of the total groundfish catch in 2006 (Alaska Fisheries Science Center 2008).

Our original study in western PWS was to determine seasonal distribution and habitat use of forage fishes. We did not anticipate, however, the frequent and sometimes large catches of saffron cod. Thus, our focus in this paper is to describe the seasonal distribution, abundance, habitat use, age, and diet of saffron cod in nearshore waters of PWS, and fill information gaps about this increasingly abundant species. Results of our study are unique because saffron cod have not been previously reported in PWS, and their increasing numbers are an indication of community reorganization in nearshore waters in the northern Gulf of Alaska.

\section{MATERIALS AND METHODS}

Study area. Prince William Sound is a prominent embayment in the northern Gulf of Alaska encompassing $\sim 5400 \mathrm{~km}^{2}$ (Weingartner 2007). Numerous islands within PWS create a mosaic of habitat types including sheltered and rocky shores, fjords, tidewater glaciers, sand and gravel beaches, eelgrass Zostera marina meadows, exposed bedrock outcrops, and cobble beaches with kelp. Our study area was in western PWS extending from waters near the city of Whittier to Latouche Island (Fig. 1). This area was chosen because $1543 \mathrm{~km}$ of shoreline was mapped with the 'ShoreZone' protocol (NOAA Fisheries 2008) in 2004, and the existing aerial imagery enabled us to identify the lin- ear shoreline extent of different habitat types. ShoreZone uses georeferenced video and digital still imagery collected during summer low tides from lowflying aircraft; imagery and commentary from flights are then catalogued into discrete along-shore habitat units (Lindstrom 2008). We chose to sample bedrock outcrops, eelgrass, and understory kelp. These habitat types do not represent all habitats available to fish, but are common in PWS and can be effectively sampled with a beach seine.

Prior to the start of field work, study locations were identified based on the presence of eelgrass. Using ShoreZone aerial imagery, we identified all shoreline segments within our study area that had at least $500 \mathrm{~m}$ of continuous eelgrass, and then randomly selected 8 locations. Upon arrival at each location, we selected a suitable eelgrass site for beach seining (e.g. approachable by skiff and free of obstructions); we then traveled by skiff from the eelgrass site to more exposed areas, often at the entrance of bays, and selected a bedrock outcrop site and an understory kelp site. We used the 'nearest neighbor' rule when selecting these other 2 habitat sites; the closest site to eelgrass that was suitable for beach seining (e.g. free of obstructions) was selected. Thus, we sampled 3 habitat types with a beach seine at each of the 8 locations (Fig. 1). Sampling occurred in April, July, and September 2006, and in July 2007. For the purpose of this study, April = spring, July $=$ summer, and September $=$ fall .

Bedrock outcrops are steep (>20\% gradient) and usually located in exposed locations near the entrance of bays; vegetation on bedrock walls is dominated by patchy to lush kelps (Laminariales such as Alaria marginata, Saccharina latissima, and Agarum clathratum). Eelgrass meadows are typically located inside protected coves or bays with flat to moderate gradient (5 to $10 \%$ ); substrates consist mostly of fine-grained sediments. In western PWS, eelgrass is minimally exposed even at the lowest tides $(-0.26$ to -0.77 m below mean lower low water, MLLW). Understory kelps occupy semi-protected areas with moderate gradient (10 to $20 \%$ ); substrates are predominantly small and large cobbles. Understory kelps are dominated by patchy to lush Laminariales, and most kelp beds are subtidal.

Fish capture. Fish were captured within $20 \mathrm{~m}$ from shore in waters $<5 \mathrm{~m}$ deep using a $37 \mathrm{~m}$ long (length of headrope) variable mesh beach seine that tapered from $5 \mathrm{~m}$ deep at the center to $1 \mathrm{~m}$ deep at the wing ends. Outer panels were $10 \mathrm{~m}$ of $32 \mathrm{~mm}$ stretch mesh, intermediate panels were $4 \mathrm{~m}$ of $6 \mathrm{~mm}$ square mesh, and the bunt was $9 \mathrm{~m}$ of $3.2 \mathrm{~mm}$ square mesh. We set the seine as a round haul by holding one end on the beach, backing around in a skiff with the other end to the beach $\sim 18 \mathrm{~m}$ from the start, and pulling the seine onto shore. The seine had a leadline and a floatline so 
that the bottom contacted the substratum and the top floated on the surface. All seine sites were sampled during daylight hours and within $2 \mathrm{~h}$ of low tide (range: +1.0 to $-1.5 \mathrm{~m}$ below MLLW).

After retrieval of the seine, the entire catch was sorted, identified to species, and counted; subsamples of up to 50 fish were measured to the nearest mm total length (TL). Only saffron cod are reported in detail in this paper. The number of fish in large catches was estimated gravimetrically: a random subsample of 500 fish was removed from the total catch and the remaining fish were collectively weighed to the nearest $0.1 \mathrm{~kg}$. Fish in the subsample were counted and weighed to the nearest gram. The mean weight of fish determined from the subsample was used to estimate the number of fish in the total catch. Fish were anesthetized in a mixture of 1:2 carbonated water to seawater for identification and measurement.

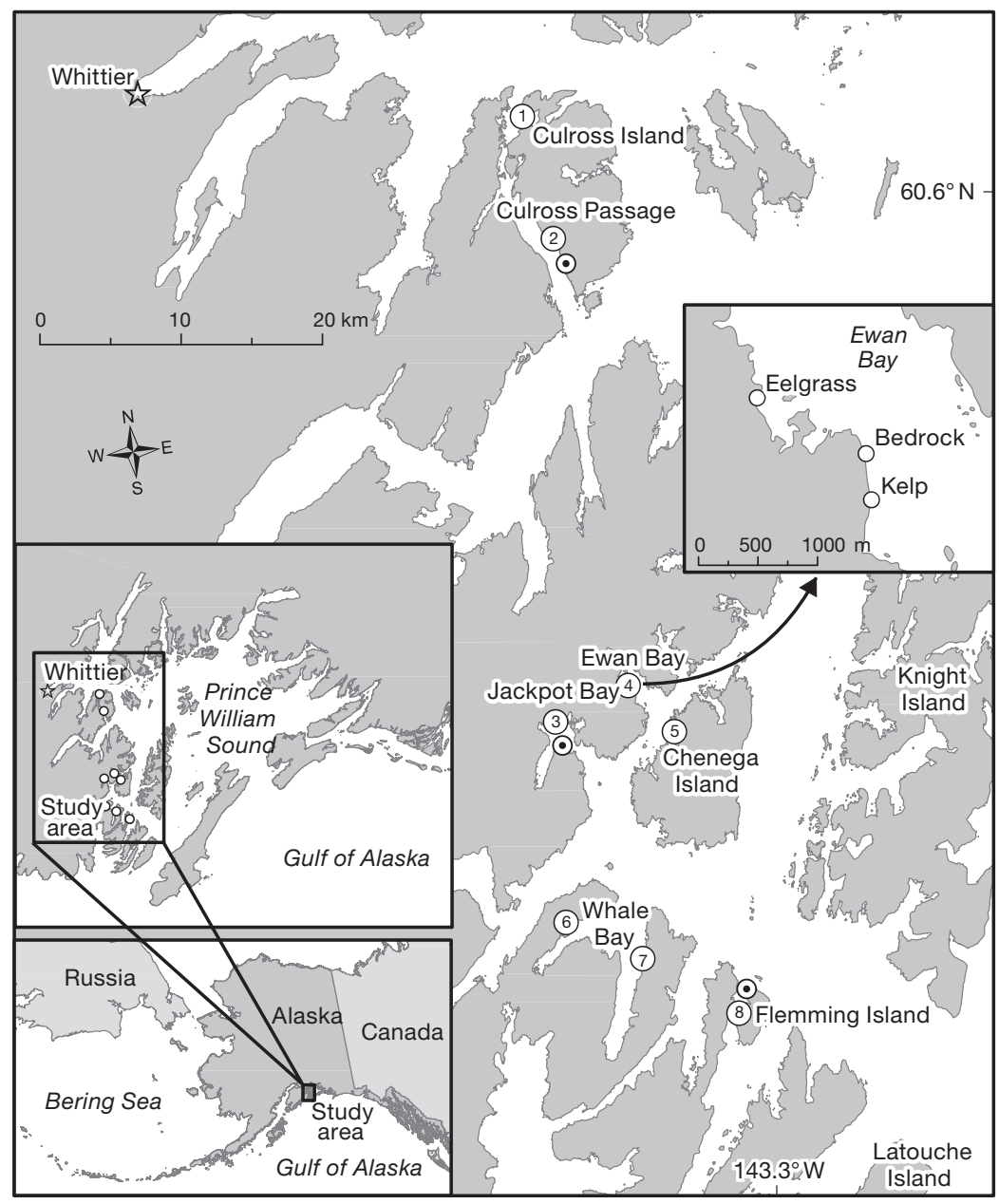

Fig. 1. Eight study locations in western Prince William Sound, Alaska. At each location, saffron cod Eleginus gracilis were sampled in 3 habitat types (bedrock, eelgrass Zostera marina, and kelp (Laminariales); see inset of Ewan Bay for an example). Fish were sampled with a beach seine in 2006 and 2007. (๑) Locations of thermographs for measuring water temperature
Age and diet. A random sample of 50 saffron cod captured in eelgrass at 3 locations in 2006 (Chenega Island, July; Whale Bay (west, location 6) and Culross Passage, September; Fig. 1) were frozen and brought to the laboratory where sagittal otoliths were removed. All otoliths were immediately examined for age while in their hydrated, 'cleared' state, supplemented by immersion in ethanol. After examination of the distal surface, cleared otoliths aged $>0$ were also inspected by the 'break and burn' technique (Christensen 1964); the transverse surface was then examined for annual growth patterns. Both methods ensured that all annuli were enumerated. All otoliths were examined using a stereomicroscope with a magnification range of 16 to $150 \times$ the normal size, and with reflected light illumination.

A random sample of 38 saffron cod (Age-0 and older) collected in eelgrass at Chenega Island and Culross Passage in September 2006 was preserved in 10\% neutral-buffered formalin and analyzed for stomach contents. Preserved fish were measured to the nearest $1.0 \mathrm{~mm}$ $\mathrm{TL}$, weighed to the nearest $0.1 \mathrm{~g}$, and stomachs were excised. Stomachs were weighed before and after removal of contents to obtain an estimate of wet weight by subtraction. Partially digested contents were examined with a dissecting microscope and identified to major taxonomic group. Taxonomic groups were combined into 11 categories. Frequency of occurrence (FO) was determined for each taxonomic group based on the percentage of stomachs in which a taxonomic group occurred.

Residence timing. In mid-July 2007, several thousand saffron cod were captured in eelgrass at Jackpot Bay (Fig. 1); 1002 fish were fin-clipped and released at the site of capture. A return to this site in late August 2007 (another study) allowed us to look for recaptures and examine residence timing.

Water temperature and salinity. TidbiT thermographs (Onset Computer) were placed at 3 study locations (Fig. 1) at approximately $-3.0 \mathrm{~m}$ depth relative to MLLW to continuously record water temperature at $2 \mathrm{~h}$ intervals throughout the entire study. Thermographs were attached to the mid-section of a $1 \mathrm{~m}$ polypropylene line; a $10 \mathrm{~kg}$ anchor was on one end of the line and a small float was on the other end. Thermographs were deployed in late April 2006 and 
retrieved in September 2006. New thermographs were deployed again in the same locations in September 2006 and retrieved in August 2007. Surface salinity (practical salinity scale, PSS) was measured at $20 \mathrm{~cm}$ depth at each seine site and sampling period with a hand-held refractometer.

Data analysis. In addition to absolute numbers (e.g. total catch), \%FO was also determined; \%FO represents the number of seine hauls in which saffron cod were captured divided by the total number of seine hauls multiplied by 100. Kruskal-Wallis ANOVA on ranks was used to test for differences in catch per beach seine haul (catch haul ${ }^{-1}$ ) among seasons and habitat types. For seasonal differences, we limited our analysis to data from spring, summer, and fall of the same year (2006). If a significant difference was found among seasons or habitat types, Dunn's multiple comparison procedure (SigmaStat 1997) was used to isolate groups that differed from each other. Annual differences (July 2006 vs. July 2007) in catch rate of saffron cod were examined by the Wilcoxon signed rank test; a CV (SD/mean) was also calculated to examine variability in total catch. Kruskal-Wallis and Dunn's multiple comparisons were also used to test for differences in length of saffron cod among habitat types. Nonparametric methods were used in all analyses because the data did not meet the assumptions of normality or homogeneity of variances even with transformation.

\section{RESULTS}

\section{Catch}

Saffron cod were abundant and widely distributed in western PWS. Inclusive of all sampling periods, an estimated 15910 saffron cod were captured in 49 of 95 seine hauls $(\mathrm{FO}=52 \%)$. Saffron cod accounted for $32 \%$ of the total catch of 49060 fish (45 species) and were captured at all locations in western PWS. Based on catch (all sampling periods, $\mathrm{n}=12$ seine hauls at each location), FO was greatest ( $75 \%$ ) for saffron cod at Culross Passage and Whale Bay (west) (Fig. 1). Other species captured in large numbers included Pacific herring (16266 fish, FO = 36\%), pink salmon (7006 fish, FO $=41 \%)$, and capelin (6670 fish, FO = $10 \%)$. Other gadids that were captured infrequently and in small numbers were Pacific cod (68 fish, FO = $17 \%$ ) and walleye pollock (422 fish, FO = 16\%).

Catch rates of saffron cod differed significantly among seasons in 2006 (Kruskal-Wallis ANOVA on ranks, $H=11.238, \mathrm{df}=2, \mathrm{p}=0.004)$ but not between years (July 2006 vs. July 2007; Wilcoxon signed rank test, $W=-2, \mathrm{p}=0.945$ ). Pairwise comparisons revealed that catch haul ${ }^{-1}$ (catch per unit effort, CPUE) in 2006 was significantly greater in summer and fall than in spring; CPUE did not differ significantly between summer and fall (Fig. 2). Total catch of saffron cod by season in 2006 was 18 fish in spring $(\mathrm{FO}=25 \%, \mathrm{n}=24$ hauls), 2358 fish in summer ( $\mathrm{FO}=63 \%, \mathrm{n}=24$ hauls), and 1210 fish in fall ( $\mathrm{FO}=57 \%, \mathrm{n}=23$ hauls). Catch of saffron cod was extremely variable between years; CV ranged from $123 \%$ in July 2006 to $261 \%$ in July 2007. One beach seine haul of an estimated 11482 saffron cod in July 2007 (eelgrass, Jackpot Bay) accounted for $72 \%$ of the total saffron cod catch.

\section{Habitat use}

Most (99\%) saffron cod were captured in eelgrass. Total catch of saffron cod (all sampling periods) was 62 fish in bedrock ( $\mathrm{FO}=19 \%, \mathrm{n}=31$ hauls), 15734 fish in eelgrass ( $\mathrm{FO}=84 \%, \mathrm{n}=32$ hauls), and 114 fish in kelp ( $\mathrm{FO}=50 \%, \mathrm{n}=32$ hauls). Catch rate of saffron cod differed significantly among habitat types (Kruskal-Wallis ANOVA on ranks, $H=39.97, \mathrm{df}=2, \mathrm{p}<0.001$ ). Pairwise comparisons revealed that CPUE was significantly greater in eelgrass than in bedrock or kelp; CPUE did not differ significantly between bedrock and kelp (Fig. 3).

\section{Age and diet}

Saffron cod ranged in age from 0 to 4 (Table 1); most fish captured were Age-0 based on length frequency (Fig. 4). Age analysis of saffron cod corroborated the large mode of Age-0 fish between 39 and $129 \mathrm{~mm}$ TL

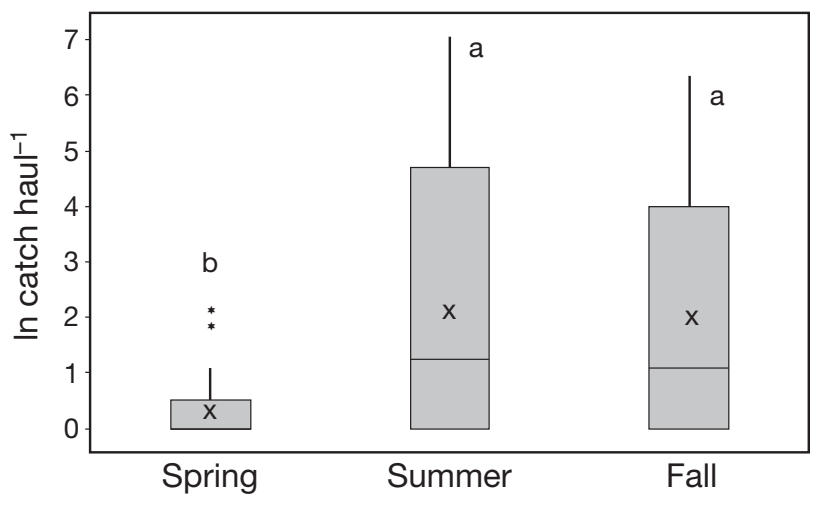

Fig. 2. Eleginus gracilis. Box-and-whisker plot of the $\log _{e}$ transformed catch per beach seine haul by season in western Prince William Sound, Alaska in 2006. Number of seine hauls: 24 in spring and summer, 23 in fall. Bottoms of boxes: first quartile; tops of boxes: third quartile; whiskers: first quartile $1.5 \times$ the interquartile range and third quartile $+1.5 \times$ the interquartile range. Within boxes, crosses are means and horizontal lines are medians. Asterisks denote outliers. Different letters above whiskers indicate significant differences in pairwise comparisons 


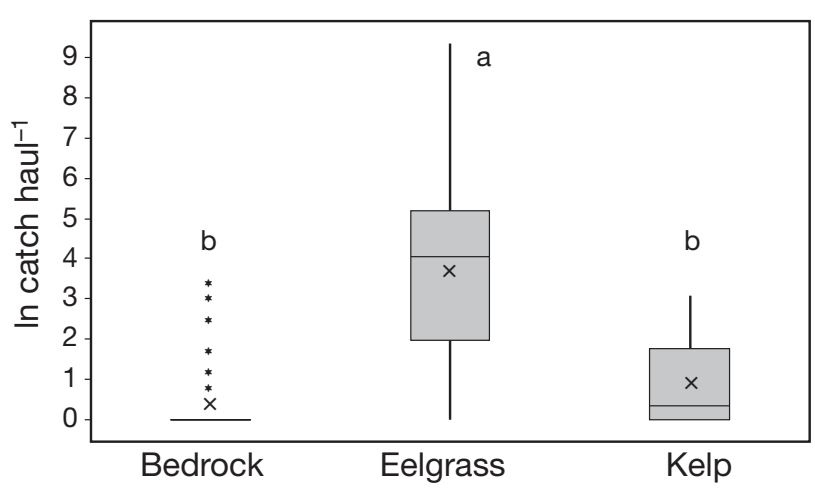

Fig. 3. Eleginus gracilis. Box-and-whisker plot of the $\log _{\mathrm{e}}$ transformed catch per beach seine haul by habitat type in western Prince William Sound, Alaska in 2006-2007. Number of seine hauls: 31 in bedrock, 32 in eelgrass and kelp. Bottoms of boxes: first quartile; tops of boxes: third quartile; whiskers: first quartile $-1.5 \times$ the interquartile range and third quartile $+1.5 \times$ the interquartile range. Within boxes, crosses are means and horizontal lines are medians. Asterisks denote outliers. Different letters above whiskers indicate significant differences in pairwise comparisons

(Fig. 4); of 50 fish aged from otoliths, 29 were Age-0 ranging in size from $55 \mathrm{~mm}$ to $117 \mathrm{~mm} \mathrm{TL}$, and 21 were >Age-0 (range $161 \mathrm{~mm}$ to $260 \mathrm{~mm} \mathrm{TL}$ ). Of 13 saffron cod from seine catches in July 2006 that were aged, 8 were Age $-0($ mean TL $=70 \mathrm{~mm}), 3$ were Age- 2 (mean $\mathrm{TL}=173 \mathrm{~mm}$ ), and 2 were Age $-3($ mean TL $=191 \mathrm{~mm}$ ) (Table 1). Of 37 saffron cod from seine catches in September 2006 that were aged, 21 were Age- 0 (mean TL = $108 \mathrm{~mm}), 8$ were Age-1 (mean TL $=204 \mathrm{~mm}), 6$ were Age-2 $($ mean TL $=204 \mathrm{~mm}), 1$ was Age-3 $(\mathrm{TL}=$ $210 \mathrm{~mm})$, and 1 was Age $-4(\mathrm{TL}=218 \mathrm{~mm}$ ) (Table 1$)$.

Captured saffron cod had a wide size range (46 to $341 \mathrm{~mm}$ TL). Size of saffron cod differed significantly (Kruskal-Wallis ANOVA on ranks, $H=89.06, \mathrm{df}=2, \mathrm{p}<$

Table 1. Eleginus gracilis. Age and size based on surface observations of annual rings on otoliths of saffron cod captured with a beach seine in eelgrass Zostera marina in western Prince William Sound, Alaska, 2006. See Fig. 1 for locations

\begin{tabular}{|lrrcll|}
\hline \multirow{2}{*}{ Age (yr) } & $\mathrm{n}$ & \multicolumn{2}{c}{ Total length $(\mathrm{mm})$} & Date & Location \\
& & Mean & Range & & \\
\hline 0 & 8 & 70 & $55-77$ & July & Chenega Island \\
0 & 14 & 110 & $103-117$ & September & Culross Passage \\
0 & 7 & 104 & $95-110$ & September & Whale Bay (west) \\
1 & 7 & 202 & $190-216$ & September & Culross Passage \\
1 & 1 & 216 & - & September & Whale Bay (west) \\
2 & 3 & 173 & $167-179$ & July & Chenega Island \\
2 & 4 & 223 & $207-260$ & September & Culross Passage \\
2 & 2 & 166 & $161-171$ & September & Whale Bay (west) \\
3 & 2 & 191 & $182-200$ & July & Chenega Island \\
3 & 1 & 210 & - & September & Whale Bay (west) \\
4 & 1 & 218 & - & September & Whale Bay (west) \\
Total & 50 & & & & \\
\hline
\end{tabular}

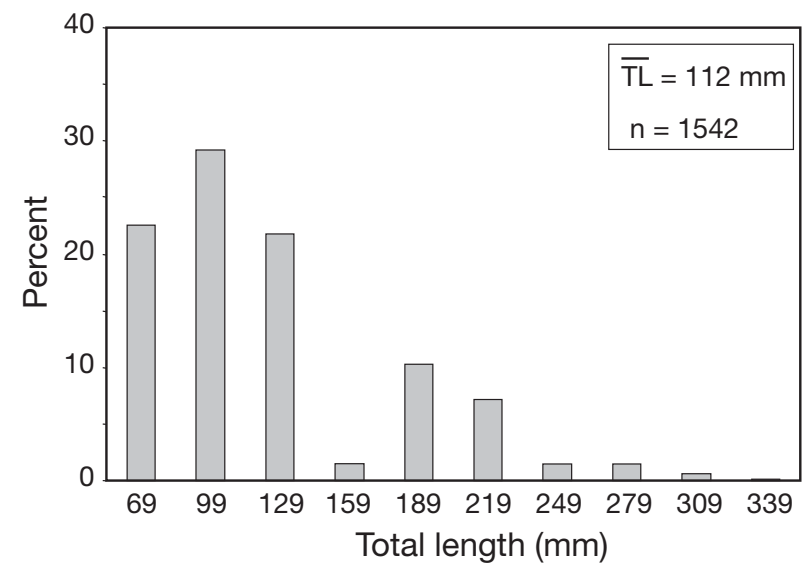

Fig. 4. Eleginus gracilis. Length frequency distribution of saffron cod captured with a beach seine in western Prince William Sound, Alaska, 2006-2007. The $x$-axis shows the upper limit of $30 \mathrm{~mm}$ intervals. TL: Total length

0.001) among habitat types. Length of saffron cod differed in all pairwise comparisons; fish were largest in kelp and smallest in bedrock. Mean TL $( \pm$ SE) of saffron cod was $71.1 \pm 3.8 \mathrm{~mm}$ in bedrock $(\mathrm{n}=62), 111.7 \pm$ $1.5 \mathrm{~mm}$ in eelgrass $(\mathrm{n}=1366)$, and $140.5 \pm 6.3 \mathrm{~mm}$ in kelp $(\mathrm{n}=114)$.

Age-0 saffron cod consumed predominantly pelagic fauna, whereas saffron cod aged $\geq 1$ targeted predominantly epibenthic fauna. Prey of Age-0 saffron cod was numerically dominated by oikopleurans; by weight, polychaetes, oikopleurans, and caprellid amphipods were the dominant food items (Fig. 5). Other organisms consumed by Age-0 saffron cod were bivalves, gastropods, decopod shrimps, harpacticoids, isopods, cladocerans, and insects; oikopleurans had the highest FO ( $60 \%)$. Prey of saffron cod aged $\geq 1$ was numerically dominated by polychaetes and crustaceans; by weight, prey of saffron cod aged $\geq 1$ was dominated by crustaceans (Fig. 5). Other organisms consumed by saffron cod aged $\geq 1$ were molluscs, gammarids, and fish; polychaetes had the highest FO (83\%).

\section{Residence time}

Most saffron cod left the nearshore area by late summer or early fall. Of 982 Age- 0 and 20 saffron cod aged $\geq 1$ that were fin-clipped and released in Jackpot Bay (eelgrass) in mid-July 2007, no Age- 0 and only 2 fish aged $\geq 1$ (179 and $200 \mathrm{~mm}$ TL) were recaptured in late August 2007 (Table 2). Total catch of 


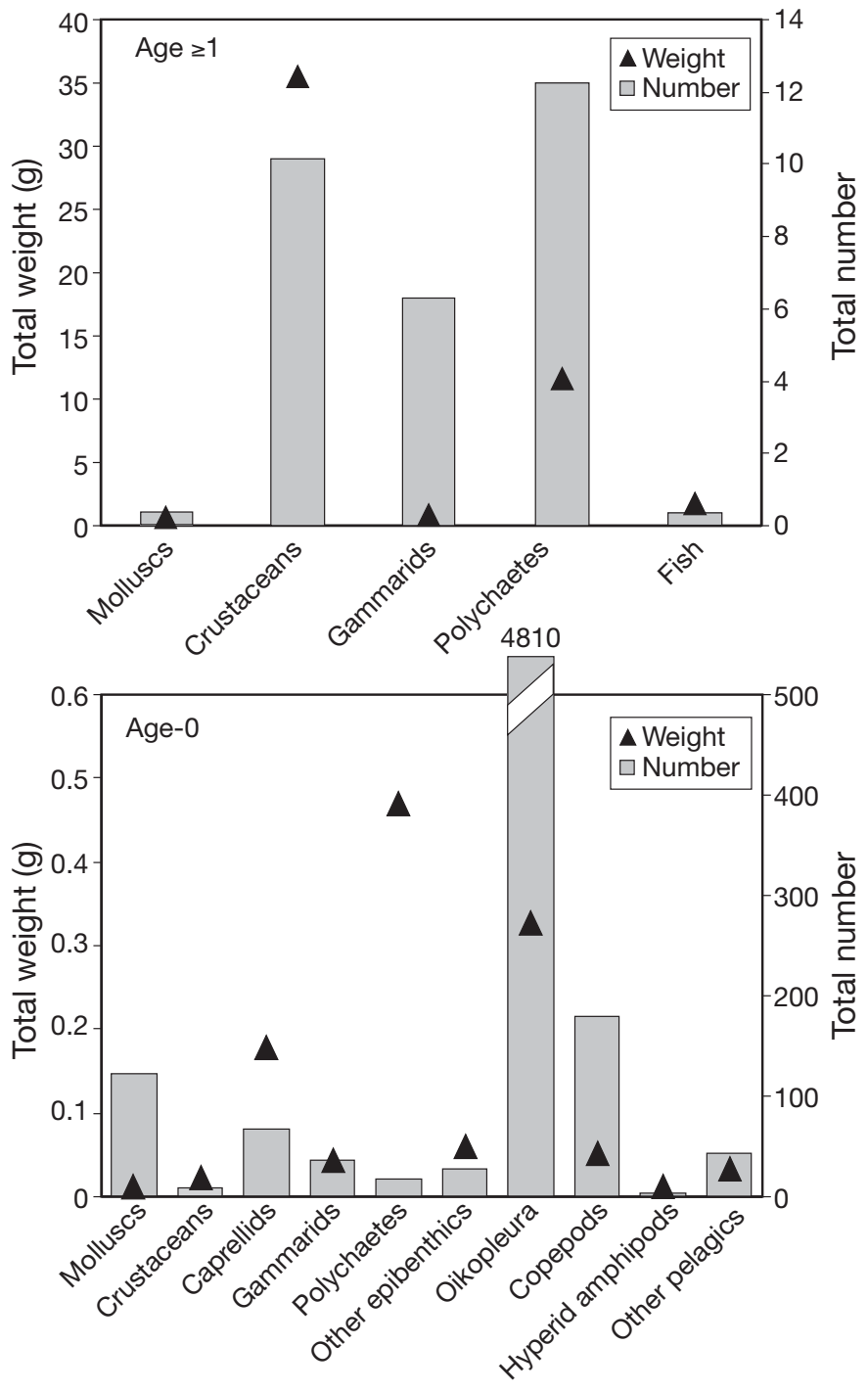

Fig. 5. Eleginus gracilis. Total weight and number of food items in stomachs of saffron $\operatorname{cod}\left(\mathrm{n}_{\text {aged } \geq 1}=18\right.$ and $\left.\mathrm{n}_{\text {Age }-0}=20\right)$ from Culross and Dangerous passages, western Prince William Sound, Alaska, 2006. Fish were captured with a beach seine in eelgrass Zostera marina. Mean total length: $220 \mathrm{~mm}$ for fish aged $\geq 1,100 \mathrm{~mm}$ for Age- 0 fish

Table 2. Eleginus gracilis. Number of saffron cod captured in eelgrass Zostera marina with a beach seine and fin-clipped on 15 July 2007 in Jackpot Bay, western Prince William Sound, Alaska. The same site was sampled again on 31 August 2007. Mean size is total length in $\mathrm{mm}$

\begin{tabular}{|c|c|c|c|c|c|c|}
\hline Date & Age & $\begin{array}{c}\text { Total } \\
\text { captured }\end{array}$ & \multicolumn{2}{|c|}{$\begin{array}{l}\text { Fish marked and released } \\
\text { No. Mean size (n) }\end{array}$} & \multicolumn{2}{|c|}{$\begin{array}{l}\text { Recaptured fish } \\
\text { No. Mean size (n) }\end{array}$} \\
\hline \multirow[t]{2}{*}{$15 \mathrm{Jul}$} & 0 & 11461 & 982 & $69(100)$ & & \\
\hline & $\geq 1$ & 21 & 20 & $178(20)$ & & \\
\hline \multirow[t]{2}{*}{31 Aug } & 0 & 187 & & & 0 & \\
\hline & $\geq 1$ & 13 & & & 2 & $189(2)$ \\
\hline
\end{tabular}

saffron cod at all locations declined by $49 \%$ from July to September 2006, whereas at Jackpot Bay, saffron cod catch declined by $98 \%$ from 11482 fish on 15 July 2007 to 200 fish on 31 August 2007.

\section{Water temperature and salinity}

Water temperatures had a similar seasonal pattern at all thermograph locations (Fig. 6), whereas surface salinity varied widely among sample sites depending on seasonal rainfall and proximity to freshwater streams. Mean monthly water temperatures were highest in July or August $\left(13\right.$ to $14^{\circ} \mathrm{C}$ ) and lowest in March (3 to $4^{\circ} \mathrm{C}$ ) (Fig. 6). Inclusive of all sampling periods, surface salinity had a mean of 22 and ranged from 5 to 33 .

\section{DISCUSSION}

Our frequent and sometimes large catches of saffron cod over a large area of western PWS indicate a reorganization of nearshore fish communities; saffron cod have not been previously reported in PWS. The dramatic increase in the abundance of saffron cod in western PWS probably occurred after 1997. In spring and early summer 1989 and 1990, Pacific cod, Pacific tomcod, and walleye pollock were abundant and were the only gadids reported in beach seine catches in oiled and non-oiled areas of western PWS (Wertheimer \& Celewycz 1996). Similarly, in summer SCUBA surveys $(1990,1996,1997)$ of eelgrass beds in the vicinity of our study locations, juvenile Pacific cod was identified as the dominant species, and saffron cod was not mentioned (Laur \& Haldorson 1996, Dean et al. 2000). The absence of saffron cod in beach seine catches in non-oiled areas of western PWS in 1989 and 1990, including Culross Passage (Wertheimer \& Celewycz 1996), strongly suggests that they were not present prior to the oil spill. The only published reference to saffron cod in PWS that we could find pertained to the diet of the blacklegged kittiwake Rissa tridactyla; the FO of saffron cod in the diet of these seabirds was small (1.5\%) in 1996 (Suryan et al. 2002) and birds could have been feeding outside of PWS.

The increasing abundance of saffron cod in western PWS appears to be a real occurrence and not a case of misidentification with other gadids. It is reasonable to assume that saffron cod could be misidentified as another gadid in SCUBA surveys but not in 


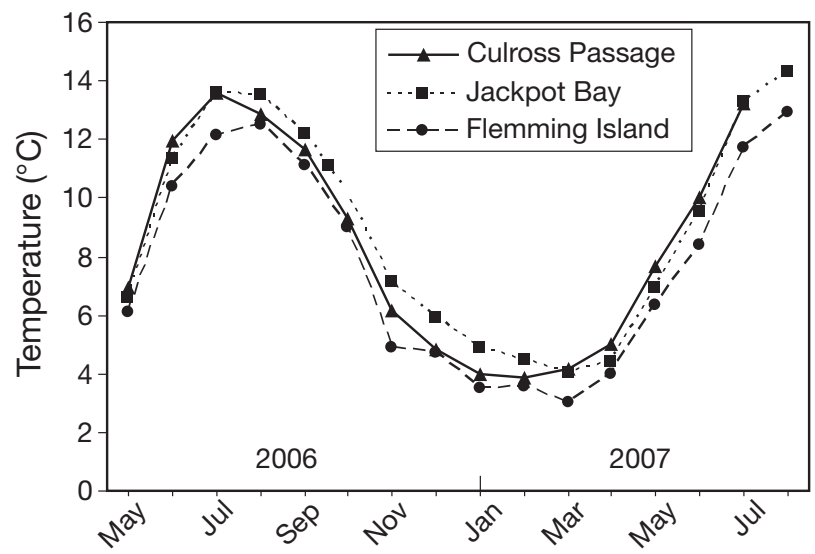

Fig. 6. Mean monthly water temperatures recorded with thermographs at 3 locations in western Prince William Sound, Alaska, 2006-2007. See Fig. 1 for locations

seine catches. On hand, saffron cod are distinguishable from other gadids by the combination of a prominent chin barbel and an interrupted lateral line from the origin of the second dorsal fin to the caudal fin (Fig. 7) (Mecklenburg et al. 2002). Even in SCUBA surveys, the slender, yellow-colored body of the saffron cod would likely be distinguishable from that of other gadids, especially the robust, orange-colored body of the Pacific cod (Fig. 7).

The cause of the dramatic increase in saffron cod abundance in western PWS is unknown, and apparently not limited to PWS. Increases in the FO and abundance of saffron cod have also been observed in other areas in the northern Gulf of Alaska. For example, in the lower Cook Inlet, Alaska, the FO of saffron cod in beach seine catches increased from $1.5 \%$ in 1976 to $8.9 \%$ in 1996 (Robards et al. 1999b) to $73 \%$ in 2008 (S. Johnson unpubl. data).

Changes in the physical environment can influence biological communities. For example, walleye pollock and Pacific cod populations increased dramatically in the northern Gulf of Alaska and in the Bering Sea after the ocean climate regime shift in the late 1970s (Piatt \& Anderson 1996, Anderson \& Piatt 1999, Overland \& Stabeno 2004). Seawater temperatures in the northern Gulf of Alaska changed from being colder than average through the 1970s to being warmer than average through the 1980s and 1990s (Royer 1993). Increases in the distribution and abundance of saffron cod in the northern Gulf of Alaska have occurred independently of the regime shift. The time interval when large numbers of saffron cod likely invaded nearshore habitats of western PWS was between

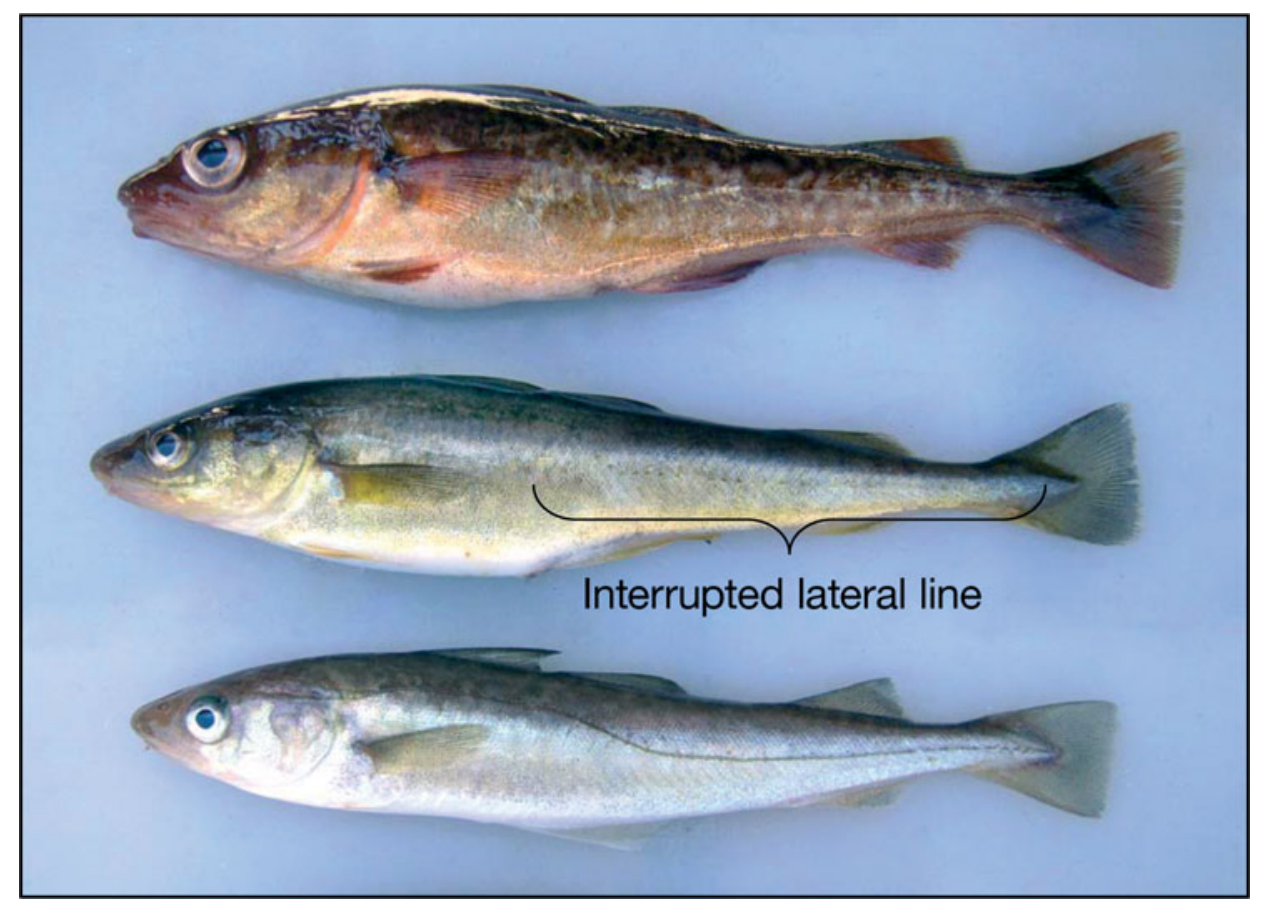

Fig. 7. Gadus macrocephalus, Eleginus gracilis, and Microgadus proximus. Morphological characteristics of Pacific cod (top, 175 $\mathrm{mm}$ total length, TL), saffron cod (middle, $182 \mathrm{~mm}$ TL), and Pacific tomcod (bottom, $175 \mathrm{~mm}$ TL). These 3 gadids have slightly protruding upper jaws and prominent chin barbels; saffron cod can be distinguished from Pacific cod and Pacific tomcod, however, by their yellowish coloration and interrupted lateral line from the origin of the second dorsal fin to the caudal fin 
1998 and 2006; seawater temperatures remained fairly stable in PWS during this time, with some warmer conditions observed in 2004 and 2005, and cool conditions observed in 2006 (National Data Buoy Center 2009). Subtle changes in the environment, however, can cause fish populations to suddenly expand. In the North Sea, red mullet Mullus surmuletus were absent in nearly 70 yr of trawl surveys until 1995 when numbers soared; warmer water temperatures in winter probably resulted in the northward migration of red mullet (Beare et al. 2005). In the northeastern Atlantic Ocean, a mass increase of snake pipefish Entelurus aequoreus has occurred since 2004, which is possibly related to climate change (Kirby et al. 2006, van Damme \& Couperus 2008). More information is needed on the effect of the environment on saffron cod distribution and abundance, especially in nearshore habitats that lack time-series data on water temperature and are often ignored in fisheries surveys.

Saffron cod are seasonal residents in nearshore habitats of western PWS. Saffron cod occupy nearshore waters for at least 5 mo (late April to mid-September), with greatest abundance in summer. Similarly, Wolotira (1985) reported that juvenile saffron cod $(<190 \mathrm{~mm}$ TL) abundance was greatest in summer at depths $<40 \mathrm{~m}$ throughout the northeastern Bering Sea and Norton Sound, Alaska. The seasonal decline in the catch of saffron cod, and the zero recovery of finclipped Age-0 fish in our study by late summer, suggest that Age-0 fish may migrate to deeper waters prior to winter. The recapture of 2 fin-clipped saffron cod aged $\geq 1$ (10\% recovery), however, provides some evidence of site fidelity in older juveniles; some fish may stay in the same eelgrass bed for several weeks.

Bedrock, eelgrass, and kelp are common habitats available to saffron cod and other fishes in nearshore waters of Alaska (Johnson et al. 2003, 2005). These habitats may be transitional areas for fish that migrate along the shoreline from one habitat to another or are utilized as foraging areas for several weeks (Johnson et al. 2008). Saffron cod were unequally distributed in nearshore habitats of western PWS, with almost all fish $(99 \%)$ captured in eelgrass $(\mathrm{FO}=84 \%)$. Similarly, at Kodiak Island, Alaska, juvenile saffron cod were almost exclusively restricted to eelgrass (Laurel et al. 2007). Based on our median CPUE of saffron cod in eelgrass (176 fish, $\mathrm{n}=16$; July 2006 and 2007) and the shoreline extent of eelgrass in our study area $(732 \mathrm{~km}$, ShoreZone), over 7 million saffron cod may inhabit eelgrass in summer in western PWS.

Our capture of mostly Age-0 saffron cod supports the importance of nearshore areas as summer nursery habitats in western PWS. Where juvenile saffron cod live in winter, however, is unknown, as is the habitat of adults. The capture of few adult saffron cod in nearshore habitats and no adults offshore in trawls in western PWS (Parks \& Zenger 1979, Bechtol 1999) suggests that adults occupy habitats that are outside the effective depth range of beach seining $(5 \mathrm{~m})$ but inshore of most trawling activity $(100 \mathrm{~m})$. In extensive trawl surveys in western Alaska, most saffron cod were found at depths $<40 \mathrm{~m}$; few saffron cod occurred at depths $>50 \mathrm{~m}$ (Wolotira 1985). Thus, a substantial biomass of saffron cod likely exists in western PWS but is missed or under-represented in most offshore sampling.

Age data derived from otoliths indicate that most saffron cod in nearshore waters of western PWS are $<3$ yr old. In Norton Sound, Alaska, saffron cod begin to mature in their third year of life (Wolotira 1985). The size range of saffron cod that we captured (46 to $341 \mathrm{~mm}$ TL) is similar to saffron cod captured in Norton Sound (60 to $350 \mathrm{~mm} \mathrm{TL);} \mathrm{in} \mathrm{Norton} \mathrm{Sound,} \mathrm{however,}$ Wolotira (1985) identified saffron cod up to Age-9, whereas the oldest saffron cod that we identified was Age-5 (fish collected in August 2007; S. Johnson unpubl. data). Growth of saffron cod may be faster in western PWS than in Norton Sound and may also differ between different locations within PWS. For example, the largest saffron cod that we captured and aged in 2006 was not the oldest (260 mm TL, Age-2); this fish was captured in Culross Passage and may represent a faster growing population compared to saffron cod captured at Whale Bay (west) (218 mm TL, Age-4). Habitat conditions in the bays and fjords of PWS are unequal in space and time, which can lead to differences in fish size and densities (Norcross et al. 2001). On a larger spatial scale, Cohen et al. (1990) reported further evidence of differences in size at age of saffron cod: Age-3 fish ranged from 188 to $354 \mathrm{~mm}$ TL in the western Pacific and between 165 and $207 \mathrm{~mm}$ TL in the Barents and Kara seas.

The few diet studies available for saffron cod are mostly from Arctic waters and focus on older fish than those in our study. In the Chukchi Sea, Coyle et al. (1997) found that pandalid shrimps were the most important item in saffron cod diets. In the Beaufort Sea, Jones \& Beste (1977) found that crustaceans and fish were the most common food items in saffron cod aged 5 to 10, and Percy (1975) reported that saffron cod consumed isopods, amphipods, pelecypods, and mysids. In Kotzebue Sound, Alaska, the diet of saffron cod (mean length: $238 \mathrm{~mm}$ ) in November was dominated by fish (Craig \& Haldorson 1981). On the western Kamchatka shelf, Chuchukalo et al. (1999) reported that amphipods, decapods, and euphausiids were the primary prey of saffron cod, and polychaetes and fish were secondarily important.

Possible implications of high saffron cod abundance in nearshore habitats include competition for food and 
space with other nearshore species and increased predation risk to commercially important and forage fish species. In western PWS, saffron cod occupy nearshore habitats with juvenile Pacific cod, walleye pollock, pink salmon, Pacific herring, and capelin. Competition for food may be highest between juvenile saffron cod and the Pacific herring; oikopleurans are the dominant food item for both species in fall (Foy \& Norcross 1999). The potential of predation on forage fishes also exists; the capelin and the Pacific sand lance have been reported in the diet of larger saffron cod (Chuchukalo et al. 1999). Whether competition for food and space or predation by saffron cod was a contributing factor, Pacific cod and walleye pollock were not very abundant in our catches compared to that of earlier studies (Wertheimer \& Celewycz 1996, Dean et al. 2000). In addition, the commercial Pacific herring fishery in PWS has been closed since 1999; reasons for the population collapse and failure to recover remain unknown ('Exxon Valdez' Oil Spill Trustee Council 2009).

We document for the first time the presence of saffron cod in western PWS. In 2006 and 2007, saffron cod was one of the dominant species in our nearshore sampling. Saffron cod represent another gadid population that has increased in the northern Gulf of Alaska, albeit more recently and in shallower water than reported for the walleye pollock and the Pacific cod with the ocean climate regime shift in the late 1970s. Changes in community structure that may result from climate change can be tracked via long-term fisheries assessment surveys to monitor stock status and harvest guidelines (Anderson \& Piatt 1999, Jackson 2008). These surveys, however, have largely been restricted to deeper, offshore waters using trawl gear. Few similar time-series surveys are in place to monitor changes in fish distribution that may occur in shallow, nearshore waters. The large increase in the FO of saffron cod in lower Cook Inlet and its abundance in western PWS indicate the species' expansion throughout the northern Gulf of Alaska. The ecological implications of increasing numbers of saffron cod in the northern Gulf of Alaska are unknown, but likely include competition for food and space and increased predation on other nearshore species.

Acknowledgements. We thank the crews of the RV 'Solstice' and RV 'Pandalus' for their invaluable support at sea; and D. Greenwell, P. Harris, K. Holderied, J. Hudson, M. Lindeberg, S. L. McConahay, J. Moran, S. Saupe, F. Sewall, M. Sturdevant, and A. Sreenivasan for help with field and laboratory work. We especially thank M. Eagleton of the NMFS regional office in Anchorage for providing logistical support and $\mathrm{K}$. Munk of the Alaska Department of Fish \& Game in Juneau for analyzing otoliths for age determination. Funding for this research was provided by the North Pacific Research Board (Project 642, Publication \#219) and the NOAA Fisheries Essential Fish Habitat Program.

\section{LITERATURE CITED}

Alaska Fisheries Science Center (2008) Walleye pollock research. www.afsc.noaa.gov/species/pollock.php. Accessed 7 Nov 2008

Anderson PJ, Piatt JF (1999) Community reorganization in the Gulf of Alaska following ocean climate regime shift. Mar Ecol Prog Ser 189:117-123

Beare D, Burns F, Jones E, Peach K, Reid D (2005) Red mullet migration into the northern North Sea during late winter. J Sea Res 53:205-212

Bechtol WR (1999) A bottom trawl survey for crabs and groundfish in the Prince William Sound Management Area, 16-26 August 1997. Alaska Department of Fish and Game, Regional Information Report No. 2A99-24, Anchorage, AK

Brown ED (2002) Life history, distribution, and size structure of Pacific capelin in Prince William Sound and the northern Gulf of Alaska. ICES J Mar Sci 59:983-996

Christensen JM (1964) Burning of otoliths, a technique for age determination of soles and other fish. J Cons Int Explor Mer 29:73-81

Chuchukalo VI, Radchenko VI, Nadtochii VA, Koblikov VN, Slabinskii AM, Terent'ev DA (1999) Feeding and some features of ecology of Gadidae of the western Kamchatka Shelf in summer 1996. J Ichthyol 39:309-321

Cohen DM, Inada T, Iwamoto T, Scialabba N (1990) FAO species catalogue, Vol 10. Gadiform fishes of the world. FAO Fisheries Synopsis No. 125, Rome

Cooney T (2007) Pacific herring. In: Spies RB (ed) Long-term ecological change in the northern Gulf of Alaska. Elsevier, Amsterdam, p 81-85

Coyle KO, Gillispie JA, Smith RL, Barber WE (1997) Food habitats of four demersal Chukchi Sea fishes. In: Reynolds JB (ed) Fish ecology in Arctic North America. Am Fish Soc Symp 19:310-318

Craig PC, Haldorson L (1981) Part 4. Fish. In: Environmental assessment of the Alaskan continental shelf. Final reports of principal investigators, Vol 7, biological studies. US Department of Commerce, NOAA Office of Marine Pollution Assessment, Juneau, AK, p 384-678

Dean TA, Haldorson L, Laur DR, Jewett SC, Blanchard A (2000) The distribution of nearshore fishes in kelp and eelgrass communities in Prince William Sound, Alaska: associations with vegetation and physical habitat characteristics. Environ Biol Fishes 57:271-287

Exxon Valdez Oil Spill Trustee Council (2009) Prince William Sound integrated herring restoration program. www. evostc.state.ak.us/. Accessed 18 May 2009

Foy RJ, Norcross BL (1999) Spatial and temporal variability in the diet of juvenile Pacific herring (Clupea pallasi) in Prince William Sound, Alaska. Can J Zool 77:697-706

Jackson DR (2003) Trawl survey of shrimp and forage fish abundance in Alaska's western region, 2002. Alaska Department of Fish and Game, Regional Information Report No. 4K03-45, Kodiak, AK

Jackson DR (2008) Trawl survey of shrimp and forage fish in the Kodiak and south peninsula districts, 2007. Alaska Department of Fish and Game, Fishery Management Report No. 08-14, Anchorage, AK

Johnson SW, Murphy ML, Csepp DJ, Harris PM, Thedinga JF (2003) A survey of fish assemblages in eelgrass and kelp habitats of southeastern Alaska. US Department of Commerce, NOAA Tech Memo NMFS-AFSC-139

Johnson SW, Neff AD, Thedinga JF (2005) An atlas on the distribution and habitat of common fishes in shallow nearshore waters of southeastern Alaska. US Department of 
Commerce, NOAA Tech Memo NMFS-AFSC-157

Johnson SW, Thedinga JF, Munk KM (2008) Distribution and use of shallow-water habitats by Pacific sand lances in southeastern Alaska. Trans Am Fish Soc 137:1455-1463

Jones ML, Beste JD (1977) Tuft Point and adjacent coastal areas fisheries project report. Aquatic Environments Limited, Calgary

Kirby RR, Johns DG, Lindley JA (2006) Fathers in hot water: rising sea temperatures and a northeastern Atlantic pipefish baby boom. Biol Lett 2:597-600

Laur D, Haldorson L (1996) Coastal habitat studies: the effect of the 'Exxon Valdez' oil spill on shallow subtidal fishes in Prince William Sound. In: Rice SD, Spies RB, Wolfe DA, Wright BA (eds) Proceedings of the 'Exxon Valdez' oil spill symposium. Am Fish Soc Symp 18:659-670

Laurel BJ, Stoner AW, Ryer CH, Hurst TP, Abookire AA (2007) Comparative habitat associations in juvenile Pacific cod and other gadids using seines, baited cameras, and laboratory techniques. J Exp Mar Biol Ecol 351:42-55

Lindstrom SC (2008) The biogeography of seaweeds in Southeast Alaska. J Biogeogr (Spec Issue) 36:401-409

Mecklenburg CW, Mecklenburg TA, Thorsteinson LK (2002) Fishes of Alaska. American Fisheries Society, Bethesda, MD

National Data Buoy Center (2009) Station 46061-Seal Rocks $55 \mathrm{~nm}$ south of Valdez, AK. www.ndbc.noaa.gov/station history.php? station=46061. Accessed 15 May 2009

NOAA Fisheries (2008) NOAA Fisheries Alaska maps, charts and regulatory areas. www.alaskafisheries.noaa.gov/maps/ default.htm. Accessed 7 Nov 2008

Norcross BL, Brown ED, Foy RJ, Frandsen M and others (2001) A synthesis of the life history and ecology of juvenile Pacific herring in Prince William Sound, Alaska. Fish Oceanogr (Suppl 1) 10:42-57

Overland JE, Stabeno PJ (2004) Is the climate of the Bering Sea warming and affecting the ecosystem? Trans Am Geophys Union 85:309-316

Parks NB, Zenger H (1979) Trawl survey of demersal fish and shellfish resources in Prince William Sound, Alaska: spring 1978. US Department of Commerce, NWAFC Process Report 79-2

Percy R (1975) Fishes of the outer Mackenzie Delta. Department of the Environment, Beaufort Sea Project, Beaufort Sea Technical Report No. 8, Victoria, BC

Editorial responsibility: Matthias Seaman, Oldendorf/Luhe, Germany
Piatt JF, Anderson P (1996) Response of common murres to the 'Exxon Valdez' oil spill and long-term changes in the Gulf of Alaska marine ecosystem. In: Rice SD, Spies RB, Wolfe DA, Wright BA (eds) Proceedings of the 'Exxon Valdez' oil spill symposium. Am Fish Soc Symp 18:720-737

Robards MD, Piatt JF, Rose GA (1999a) Maturation, fecundity, and intertidal spawning of Pacific sand lance in the northern Gulf of Alaska. J Fish Biol 54:1050-1068

Robards MD, Piatt JF, Kettle AB, Abookire AA (1999b) Temporal and geographic variation in fish communities of lower Cook Inlet, Alaska. Fish Bull 97:962-977

Royer TC (1993) High-latitude oceanic variability associated with the 18.6-year nodal tide. J Geophys Res 98:4639-4644

Ruccio MP (2003) Trawl survey of shrimp and forage fish abundance in the Kodiak district, 2001. Alaska Department of Fish and Game, Regional Information Report No. 4K03-4, Kodiak, AK

SigmaStat (1997) SigmaStat statistical software. SPSS, Chicago, IL

Smith RL, Paul JM, Gillispie J (1997) Energy content of Arctic cod and saffron cod in the northeastern Chukchi Sea. In: Reynolds JB (ed) Fish ecology in Arctic North America. Am Fish Soc Symp 19:319 -325

Suryan RM, Irons DB, Kaufman M, Benson J, Jodice PGR, Roby DD, Brown ED (2002) Short-term fluctuations in forage fish availability and the effect on prey selection and brood-rearing in the black-legged kittiwake Rissa tridactyla. Mar Ecol Prog Ser 236:273-287

> van Damme CJG, Couperus AS (2008) Mass occurrence of snake pipefish in the northeast Atlantic: result of a change in climate? J Sea Res 60:117-125

Weingartner T (2007) The physical environment of the Gulf of Alaska. In: Spies RB (ed) Long-term ecological change in the northern Gulf of Alaska. Elsevier, Amsterdam, p 12-17

Wertheimer AC, Celewycz AG (1996) Abundance and growth of juvenile pink salmon in oiled and non-oiled locations of western Prince William Sound after the 'Exxon Valdez' oil spill. In: Rice SD, Spies RB, Wolfe DA, Wright BA (eds) Proceedings of the 'Exxon Valdez' oil spill symposium. Am Fish Soc Sym 18:518-532

Wolotira RJ Jr (1985) Saffron cod (Eleginus gracilis) in western Alaska: the resource and its potential. US Department of Commerce, NOAA Tech Memo NMFS-F/NWC-79

Submitted: February 18, 2009; Accepted: July 15, 2009

Proofs received from author(s): September 1, 2009 